\title{
The Relationship of Social Pedagogy and Social Work
}

\author{
Blahoslav Kraus ${ }^{1}$ \\ Stanislava Hoferková ${ }^{2}$
}

\section{Contacts to authors}

1,2 University of Hradec Králové, Faculty of Education, Rokitanského 62, 50003 Hradec Králové blahoslav.kraus@uhk.cz stanislava.hoferkova@uhk.cz

\section{Kontakty na autory}

1,2 Univerzita Hradec Králové, Pedagogická fakulta, Rokitanského 62, 50003 Hradec Králové blahoslav.kraus@uhk.cz stanislava.hoferkova@uhk.cz

Copyright (C) 2016 by authors and publisher TBU in Zlín. This work is licensed under the Creative Commons Attribution International License (CC BY).

\begin{abstract}
The article analyses the development of the relationship between social work and social pedagogy at the end of the 20th century in the Czech Republic and compares this relationship to the one in neighbouring countries (Germany, England, France, Switzerland, Denmark, Sweden, Finland, Poland, Slovakia, Russia, Lithuania). The article further deals with various concepts of this relationship (including identification, differentiation, and convergent principle). It also compares the paradigms of social pedagogy and social work (autonomy, similarities and differences mainly in epistemological terms). Series of paradigms appear in both social work and social pedagogy during their development. A prevailing tendency towards the multi-paradigmatism can be seen. Furthermore, the article discusses the differences in professional aspirations within both fields and the number of job opportunities for the fields graduates. A conclusion of the article is dedicated to the professional career within social pedagogy and social work regarding the real life situation in both fields.
\end{abstract}

Keywords: social pedagogy, social work, development of paradigms, pedagogization, social education

\section{Ke vztahu sociální pedagogiky a sociální práce}

Abstrakt: Cílem studie je identifikování konvergentních a divergentních prvků sociální práce a sociální pedagogiky prostřednictvím obsahové analýzy a komparace. Výzkumný soubor tvoří vědecké a odborné texty slovensky, česky, německy nebo anglicky píšcích autorů, s důrazem na definování obou disciplín a priorizaci slovenské a české jazykové oblasti. Ve studii identifikujme konvergentní a divergentní prvky sociální práce a sociální pedagogiky jako dvou jedinečných disciplín a profesí, přikláníme se $\mathrm{k}$ názoru, že sociální pedagogika je teoretičtější a všeobecnější, zatímco sociální práce je praktičtější a vědou více aplikovanou, avšak pro obě disciplíny je důležitá intenzivní spolupráce usilující předně o prevenci sociálně patologických jevů ve společnosti a vedoucí $k$ zdravému fyzickému, psychickému a sociálnímu vývoji jedince.

Klíčová slova: sociální pedagogika, sociální práce, vývoj, paradigma, pedagogizace, sociální výchova 


\section{Genesis and concepts of social work and social pedagogy}

Concepts of social work and social pedagogy vary regarding the genesis of each field. Both disciplines have special status within the system of science disciplines in the Czech Republic. Even though social pedagogy has longer tradition (more like a way of theoretical thinking than a science discipline) it gained fundamental position as well as social work after the year 1990. Both disciplines have undergone interesting development since then. Common phenomenon of both fields is their still increasing professionalisation, increasing importance from the theoretical and practical point of view, and an interest in their study.

Some roots of social work can be found during the period of First Republic in connection to the figure of Masaryková. However, the social work did not exist as a science discipline and its development started after the year 1990, it was conducted at sociological workplaces within the Anglo-American concept which distances itself from the social pedagogy. To this can be added that pedagogy is not taught anywhere in the Czech Republic as a part of social work. Association of Educators in social work does not even include social pedagogy in a minimum standard study plane.

An initial discussion regarding the legitimacy of social work as a scientific discipline resulted in an opinion that social work has defined itself as an individual, integrated science discipline (separate workplaces at universities are taken as evidence of that fact). Social work undergone longer-term and more extensive development in western countries. In the broadest sense it is generally defined as a scientific field engaging in activities that prevent or solve the problems of individuals and groups, rising from the conflict between the needs of an individual and social institutions, with the intention of improving quality of life. In real life it is a realisation of social policy. Social work enters the social policy when the needs of citizens are not adequately met.

In that context it mainly provides these functions:

a) Curative - social work removes barriers, dysfunctions, and their results from life of an individual that prevent his or her optimal development.

b) Stimulatory - social work secures a harmonic relationship of an individual and a society.

The state of social pedagogy (its roots go back to G. A. Lindner) must be described as chaotic mainly in the first years after the velvet revolution (see Kraus, 1996). At the beginning the term "social pedagogy" was used to describe whole methodological approach to pedagogy in its broad sense, as well as the individual discipline that was (before the revolution) called educational theory. Nowadays the term social pedagogy is clearly defined as an individual scientific discipline, which has strongly multidisciplinary and integrating character.

Social pedagogy focuses on the everyday life of the individual, analyses his or her life situations and creates such changes of social environment so as to help to optimize a personality development, and minimize the discrepancy between an individual and a society. Emphasised is socio-educational help for vulnerable groups of children and youth, and educational work with marginal groups. Main theme of the whole field is a development of social creativity and an activation of everyone's individual power. It also focuses on a development of individual's healthy lifestyle regarding his or her individual abilities (Kraus, 2014).

In any case, we accept the broader concept of social pedagogy, according to which is this discipline focused not only on problems of pathological character, marginal groups, on parts of populations that are at risks of their development, and on people with potentially deviant behaviour, but also, primarily, on the whole population in terms of creating a harmony between the needs of an individual and a society, in terms of creating an optimal way of life in a given society. 
Basic functions of social pedagogy are:

- Preventive (to minimize all threats to optimal social development and to prevent deviant behaviour).

- Compensational (to compensate all disadvantages, handicaps, and to correct behaviour deviations).

In Germany both disciplines have many years of tradition even though the origin of every discipline can be found in different historical period. Whereas social pedagogy and social pedagogical work can be traced to the middle of nineteen century, the concept of social work is forming after the Second World War. Further development has, mainly in recent years, strongly integrative character. The coordination board, lately working in Germany on ensuring comparability of education programs across the federation, is recommending to replace the existing dualism (two titles are used Sozialpadagogik/Sozialarbeit) by one title Soziale Arbeit which is more in accordance with the AngloAmerican concept of "Social Work." This concept is related to the overall status of pedagogy as such in those countries.

According to the Huppert and Schinzler (1995), activities of a social nature relate to both fields and boundaries are drawn artificially. As Wagner declares, social work and social pedagogy have homogeneous professional paradigm, and the question is, weather it means a unity of both disciplines or maintaining their own autonomy (including the fact that social pedagogy is viewed as being more academical discipline than social work). Wagner advises to maintain some autonomy of both disciplines even at the price of certain dualism (Wagner, 1998). Schilling believes that even though both fields had common historical roots, in the 20th century they had evolved into relatively independent fields, and its current trend is towards convergence (Schilling, 1999).

In Switzerland there is a similar view on social pedagogy and social work. "Although in real life practice the fields of social work and social pedagogy are increasingly overlapping, in the theoretical studies separate approaches are still applied. In the near future, however, an integration is assumed" (Hochstrasser, 1991, p. 21).

In other western countries social work has usually longer and grater tradition than social pedagogy. In English speaking countries the socio-pedagogical issues, and theoretical issues regarding education in general are being dealt with in terms of sociology (or psychology), and therefore the term social pedagogy is rarely to be seen. Recently is the situation changing and social pedagogy is being discussed. A proof of this is the book by Camerona and Mosse (2011) "Social Pedagogy and Working with Children and Young People" or the journal "International Journal of Social Pedagogy," which is being published since 2012 and aims to support a discussion about social pedagogy in English speaking countries (International Journal of Social Pedagogy, 2006). The current state of both disciplines is described in the third part of this paper.

Different situation is in Poland. Here the field of social work started to develop from the discipline of social pedagogy, which has a longer tradition in Poland. Social pedagogy was seen as methodological and theoretical base, and therefore, the founder of pedagogy Radlinská viewed the social work as a branch of social pedagogy, other branches being: educational provident, cultural educational work, and educational health care (Pilch \& Lepalczyk, 1995). Social work is seen as a practical activity for helping individuals and families that got into difficult situation in life with the aim of their full participation in society. It is recently developing as an independent science discipline regardless the social pedagogy (Brągiel, 2001).

In Slovakia, the development was similar. It was given mainly by the fact that the field of social work was forming mostly at pedagogical work places (departments and faculties), namely in Banská Bystrica, Prešov, Bratislava. Consequently, it also formed the view on the relationship of both disciplines. Further development of both disciplines lead to convergence (Hroncová, Hudecová, \& Matulayová, 2001). Social work has gained, nowadays, an independent status as a field of science, it 
has its own scientific support and independent workplaces. It justifies a different concept and a significant shift to the aforementioned Anglo-American model. To this situation that is similar to our situation, Kratochvílová says: "It is alarming that study plans of social work, at some faculties, are missing pedagogical disciplines. I believe that this mistrust and neglect of pedagogy is the result and a relic from the period of excessive criticism after the social changes in 1989, when pedagogical disciplines were criticised not only for its theories marked by the regime, but also for the mistakes and failures in a practical implementation of a school policy" (Kratochvílová, 2001, p. 422).

In Lithuania, the social work and social pedagogy began to intensively develop in the 90s. Currently they are perceived as distinctive and independent disciplines. Social work is developing on the basis of sociology and social pedagogy is based on education science. Even though the profession of social worker and social pedagogue are regulated by different resorts, both pursue similar goals and are often using the same methods and means to achieve them (Leliūgienè, Giedraitienè, \& Rupšienè, 2006). In Lithuania, social pedagogue became a part of a school assistance system and is perceived as specialist, who cares for the solution of children's social problems at an educational institution - school, kindergarten, children's day centre, care institution (Vaitkevicius, 1995; Leliūgienè, 2003).

In Russia, the 90s were, as well as in our country, the period of searching. It was a time when social pedagogy, being a relatively new discipline, was defining itself, and was defining the relation to the other scientific disciplines not only to pedagogical disciplines including social work. According to Lipskij, social pedagogy is mainly theoretical discipline whereas social work is a practical approach in real life (see Lipskij, 2004). Lipskij notes significant development in both fields in response to the development of a social sphere of the whole society. He addresses gnoseological and methodological basis of social pedagogy, he deals with technologies and processes in socio-pedagogical practice. The work of Nikitin and others (2002) is, by its approach, closer to the practical use. It defines social pedagogy in a broad sense as pedagogical aspects of social development of an individual, so called "social functioning", and social activities. The main topic is the educational assistance in the whole socialization process, and its regulation. Nikitin also focuses on socio-pedagogical profession, including activities associated with social work in to the field of social pedagogy, mainly in fields of children's and youths social-rehabilitation, and a work with people with personality disorder, socially maladjusted people, including penitential care and "corrective" re-socialization pedagogy.

\section{Paradigms of social pedagogy and social work}

Concept of paradigm is not unambiguous. Accepting the basic definition by Kuhna, who perceives a paradigm as a set of generally recognized scientific results representing, in a given time, a model of issues and their solutions, for a given group of academics (Kuhn, 1997, p. 10), we must find the situation confusing in both fields, social work as well as social pedagogy. As has been already mentioned, several paradigms appear in both fields.

A. Regarding social work paradigms, there have been several of them during the course of its development. Charitable paradigm (its essence was actually missionary work among atheists), medical paradigm (it was an effort to get to know the social context in which the client lives on the basis of "social diagnosis" and to propose an adequate way of helping him or her - "social therapy"), psychotherapy (applying a psychoanalytical approach in order to understand client's personality, and to act also preventively within the "field therapy") Next model is a sociological paradigm that turns the attention of social workers from internal to external causes (client's social and economical conditions) and the social worker takes the role of a "social reformer." A relatively recent model, which appeared in the $80 \mathrm{~s}$, is the paradigm of a manager, where a client becomes a customer and into a social work vocabulary are getting expressions like market, competition, commercialization, supply, demand, etc. (Kappl, 2008). 
The last decades show that it is not possible to rely only on one concept, and therefore, at the end of the 90s, Payne brings the concept of "small paradigms" (Payne, 1997).

1. Reflexivly-therapeutical: the aim of social work is to help to secure a psychosocial well-being of an individual or group. Social work is a reflexive process through which clients can gain control over their own lives.

2. Socialy-collectivistic - according to which people are gaining an influence on their lives by the help of socio cooperation and solidarity. Social work aims to strengthen people's consciousness in order to participate on the creation and modification of institutions, to contribute in changing the social order, and to create a society based on equality.

3. Individualistically-reformational - this concept sees the social work as one aspect of a whole system of social services. Its aim is to meet the individual needs and to try to improve social services. It means helping mainly by providing information, qualified advice, and making resources available. It is a change in society and its institutions in order to be able to suite to the needs of its citizens (Navrátil, 1998).

The concept of Ondrejkovič (2000) is also based on the above mentioned point of view:

1. Therapeutic - based on client principal; It's about helping individuals and groups in order to restore a distorted balance in the functioning of society. Main condition is a serious social diagnosis.

2. Consulting - based on consulting service regarding legal issues, psychological problems, relationships (domestic violence), and social issues (unemployment).

3. Reform paradigms - it focuses on problem solving strategies on the macro-social level including social policy, economy, with the aim of effective social planning (for example help for the whole region)

4. Educational - teaching social skills, pro-social education, helping with multicultural issues solutions, re-qualification, etc.

According to DuBois and Miley, the aim of social work is to ensure that clients will no longer need the help of social worker, and also that clients will be able to manage their problems on their own, what's more to ensure that they will not get in to the problems at all in the first place.

The title Social Work - An Empowering Profession, defines the aim of social work as an effort for awaking manpower so everybody will be able to update their skills and knowledge. This is the mission of modern social work - empowering clients to solve their problems by themselves, enhance human ability to cope with their lives and operate efficiently. According to the authors, social work performs three functions (DuBois \& Miley, 1992):

1. Consulting - its core is the client's problem.

2. Resource management - use and coordination of social services, connecting clients with the formal and unofficial resources.

3. Educational.

B) Looking in history for paradigms of social pedagogy we will find, similar to social work, charity paradigms, therapeutic paradigms, consulting and especially educational paradigms.

Ondrejkovič mentions therapeutic paradigms, including individual help, crisis intervention (quick help), socio-therapy (a set of steps having a positive impact on life situation of people, who are at risk regarding negative phenomena), counselling paradigms (crisis and drop-in centers, helplines, pedagogical and psychological counselling, premarital counselling), educational paradigms (healing pedagogy, retraining, preventive programs), macro-social paradigms (social planning, solving 
problems on the macro-level, being consistent with state social policy) (Ondrejkovič, 2004). Knotová (2004) speaks about these paradigms: counselling, anthropological and re-educational.

A trend towards multi-paradigmatism is clear from above mentioned approaches. In this spirit is social pedagogy described in a book Man-Environment-Upbringing (Člověk - prostředí - výchova) with subheading Questions of Social Pedagogy (K otázkám sociální pedagogiky) by Kraus and Poláčková et al. (2001). Here is social pedagogy presented as a scientific discipline of transdisciplinary nature focusing on the role of environment in upbringing and education not only in connection to the problems of disadvantage groups that are at risk, potentially deviant acting groups, vulnerable groups, but also in connection to the whole society by creating a harmony between the needs of individuals and the society and contributing to the optimal way of life at a given time in a given social conditions. Similarly is social pedagogy seen by Kraus (2014) in his new work Basics of Social Pedagogy (Základy sociální pedagogiky).

Huppertz and Schinzler are bringing an interesting point of view, arguing that social pedagogy/social work fulfil these functions (Huppertz \& Schinzler, 1995):

- Pedagogical (contributing to the optimal development of personality, formation of a lifestyle).

- Preventive (activities and programs contributing to the prevention of various deviations).

- $\quad$ Compensation (activities balancing deficits from e.g., a very little stimulating environments).

- $\quad$ Correction (activities related to population placed in jails, institutions, homes).

- $\quad$ Tutorial (e.g. legal assistance and protection for those who find themselves on the margins of society).

- Structural (influencing processes relating to living conditions at the macro-social level, e.g., in the field of employment).

- $\quad$ Distributive (help and work with refugees and immigrants).

Noack defines in publication titled Sozialpädagogik the scope of social pedagogy as: leisure time and education experience, socio-cultural work, work with children and youth, work with families, work with the elderly but also work with the unemployed, the homeless, helping those who are dependent, advice on debt (Noack, 2001). Again, it is clear that these concepts mingle the areas of social pedagogy and social work.

In both social work and social pedagogy can be found some basic paradigms that can be summarized as follows: counselling, therapeutic, re-educational, reform (structural), and also a paradigm that is crucial for social pedagogy, educational. From some points of view, prophylactic paradigms are integrated in social work

Paradigm stressing educational aspect of social work is based on the opinion that the social work activities have educational character and that there are not many activities without educational aspect in them (Tokárová et al., 2003). It should be noted that this paradigm is accepted very rarely in the Czech Republic. Mollenhauer (1966) states that the activities that cannot be seen as pedagogical phenomenons are slowly disappearing.

\section{Context and specifics of social pedagogy and social work}

Social work that excludes pedagogical aspects is based, uncritically, on American "Social Work." It copies the system that originated in different social and historical conditions and today does not exist in its original form. Strict rejection of pedagogical aspects in social work relates to false notions of pedagogy associated with traditional paternalistic activities, authoritarianism in the family and at 
school. On contrary, social work often takes on socially progressive pedagogical approaches and solutions (e.g., group work, individual approach of education reform, intervention into the client's environment, etc.) (Ondrejkovič, 2000). Additionally, both areas benefit from disciplines like sociology, psychology, law, medicine, and others.

It can be said that, overall, there are three possible views on the relationship between the two disciplines (Ondrejkovič, 2000):

a) The first approach, used in German-speaking countries, is a unification of both disciplines.

b) The second approach, typical for English-speaking countries, represents a clear differentiation of both fields (if social pedagogy is even mentioned).

c) The third approach, is based on integration while maintaining a certain independence of both disciplines (this approach is typical for Slovakia, and in a certain sense, Poland).

The first approach, in addition to already mentioned German authors, holds also Pfeiffer (1994). Social work and social education are, according to Pfeffer, disciplines dealing with certain professional conduct in the given society, which is predetermined by the normative foundations of that society. Social work is referred to as a practically oriented science that must necessarily take into account the living conditions of the clients. Noack (2001) sees social work as part of social education and speaks about social pedagogical work. Erler also highlights the conceptual ambiguity, both terms are understood essentially as synonyms and their differentiation, according to him, lies in the core of the individual discipline that is either in social care (social work), or in social education activities (social pedagogy) (Erler, 1993).

There is a consensus that in practice socially educational activities are closely associated with social work. Solution of the scientific identity of both disciplines is still stimulating a discussion. In any case, both fields, relating to social development, consistently pursue a goal of an active improvement of life quality (Braches-Chyrek \& Süncker, 2009).

The second approach is typical for the USA, Great Britain and other Western countries that have adopted this model. As has been already mentioned, the situation is slowly changing in recent years. In England during the 90s within the concept of social work, social pedagogy is beginning to be mentioned referring to the German tradition, pointing out that it could enrich individualistic conception of the English understanding of the concept of social work (Szmagalski, 2010). Petrie also played an important role in the development of social education, in addition to the already mentioned Cameron. Both understand social pedagogy as a discipline that forms the basis of educational and care work with children and youth, especially in orphanages. Following the European tradition they define four basic areas where is the social pedagogy applied: theory of education in the environment, education policy, social and educational work with children and youth, and education of social workers (Petrie \& Cameron, 2009; Petrie, 2001).

In France, social pedagogy is not understood as a separate discipline, it is more about pedagogical reflection of serious topics regarding socio-educational activities in connection with the psychoanalytic theories, humanistic psychology and pedagogy, and critical pedagogy. Such socioeducational topics then become part of the professional preparation of educators, social and cultural animators and social workers (Bon, 2009).

Social pedagogy is discussed also in the Northern countries, discussions are about epistemological and ontological questions of social pedagogy (Hämäläinen, 2003). For example, in Sweden is the social pedagogy increasingly perceived as an important theoretical concept for the development of social work as well as having practical applications in the fields of social work, but it is not perceived as an individual discipline. Social Pedagogy seems to be a current issue mainly in connection with the growing social problems and their solving process, and in cooperation with social work and special need education (Eriksson \& Markström, 2009, 2004). Similar situation is in Finland, where Hämäläinen defines social pedagogy as meta-theory of social work. According to him, social workers, 
who work in different environments, must have knowledge and skills in the field of social education, social mobilization and personal social development (Hämäläinen, 1989).

Also in Denmark is social pedagogy viewed as an academic discipline that has its own place within the academic teaching. It is defined as a wide range of integration activities, which develop personality, and skills necessary for life in contemporary society. It establishes forms of social work prioritizing help to individuals with integration into society and in a processes of helping and learning (Madsen, 2006). Social pedagogy is reflected in education and care work of social workers and pedagogues, who work with children and youth in their environment, in support of families, seniors and other socially disadvantaged groups.

The third concept of social pedagogy is typical for Poland. Marynowicz-Hetka (2008), understands social work as a field of social effects of various subjects that help in individual development, social groups to overcome difficult life situations. In this context social pedagogy brings aspects axiological, anthropological, and educational, into the social work and is giving it a sense, wholeness, and educational foundations in terms of an individual and a society. Socio-pedagogical perspective on social work can be conceptualized as field of social worker's impact based on social interaction. Social pedagogy also helps to clarify the mechanisms of designing and shaping the environment. Radziewicz-Winicki states that social pedagogy creates theoretical and philosophical basis for social work and is bringing an educational aspect into it (Radziewicz-Winicki, 2008). A remarkable work in this aspect is the work of Kantowicz (2013) Pedagogika (w) pracy socjalnej. Kantowicz draws attention to educational aspects of social work primarily in connection with strengthening the client's ability to be active and using knowledge of social pedagogy about the social environment.

As has been already mentioned, this approach prevailed also in the Slovak Republic. According to Hroncová, Hudecová and Matulayová (2001), social pedagogy is a theoretical and general science, which stresses socio-educational aspects in the relationship with a person who found himself in need and also helps to prevent dysfunctional processes in human lives by intentional intervention into their lives. Strieženec (2000) emphasizes the need of cooperation of both disciplines. According to him, they have a common object of interest (a person), subject (social activity in a social environment), humanistic approach (human assistance). As has been already stated, even though, both disciplines have similar roots, social work has earned an individual position, as verified by Tokárová. According to her (2008), a certain autonomy of both fields manifests itself as follows: Social work as a scientific discipline is based on social policy, while social pedagogy on educational policies, and in a same time there exists a certain bond between them. Social pedagogy is rooted in educational science and social work is connected to the wide range of scientific disciplines.

We therefore believe that the optimal approach regarding the development of both disciplines is the third one. The situation in the Czech republic, as has been already mentioned above, however, is different, and only further development will show what direction it will take. To clarify the third point of view, we can state that both disciplines have essentially the same functions, similar professional paradigm, but also its own autonomy. For example, in an object of their interest and operation. The concept of social pedagogy in our country, unlike social work, considers alongside specific population categories, minorities, basically the entire population.

Intensive studies and scientific reflection of socio-educational reality led, by Levická (2002), to adoption of definitions of both disciplines and to consideration of the following facts:

1. Social pedagogy is an individual pedagogical discipline (that is understood as a discipline oriented on help in life) which aims, in a system of complex care, to provide help for children, youth, and adults in different types of an environment by finding optimal forms of help and by compensating various deficits.

2. The basic methods of social pedagogues, used in practice, include pedagogical methods.

3. Social pedagogy includes mainly educational activities. 
4. Social work grew out of the real need of society to handle socially difficult situation of its members, it is society's responses to undesirable social phenomena.

5. Social work abroad is characterized by the advance theory of social work, and in most countries it is accepted as a separate profession.

6. Identification with the assertion that the social work is using teaching methodologies.

If the aim of social work is to help the client to understand their own situation, to adapt to the changed conditions, to acquire new skills, to take an active part of a community life, then a social worker aims to achieve an optimum degree of harmony between the client's needs, rights, requirements and his or her real possibilities that are significantly influenced by the client's environment. In real life it means that social work intentionally uses pedagogical methods in order to help individuals to prepare to take an adequate role in a society (focusing on socialization), and in order to help to manage and cope with significant changes in their lives.

In contrast, the social pedagogue is preparing individuals for their entry into the widest social environment, is equipping him with an arsenal of required knowledge and skills the individual needs in order to be fully capable of social integration in its broadest sense. This pedagogical effort is nowadays focused more on acquiring a certain amount of skills, so called social skills, especially problem solving skills, civic engagement, or critical thinking competence, solidarity thinking and acting, and the development of individual skills so they contribute to the comprehensive development of an individual as a social being. It offers help in the form of education and social education for individual age groups, not only by methodical processes, but also by appropriate organizational forms. Social pedagogy is a meaningful response to the requirement of permanent renewal and expansion of knowledge and skills of individuals so as to maintain their full social functioning and quality of life.

Differences and the autonomy of both fields can be, therefore, seen especially, depending on the angle of view, from the epistemological perspective. And even if this perspective was very close, it is always better to have two view points than only one.

It is evident that some differences can be found in a theoretical definition of both disciplines:

1. Firstly, "definition of the situation." While social work is mainly focused on solving adverse social events, a situation that has already occurred, the social pedagogy is focused more on prevention.

2. Consequently, the second difference, described as "specification of the target population." Social pedagogy focuses on the entire population that is lead, by it, to a healthy lifestyle, whereas social work has its target population "that has been already filtered". "The filter" is represented by a certain socially problematic situation.

3. The third difference arises from the "tools" used by both disciplines. Social pedagogy uses social education as a tool for leading clients to optimal personality development and a healthy lifestyle. And education in general is defined as deliberate process of personality formation. Social work focuses more on changing the behaviour of individuals than on changing their personality. Different view, therefore, concerns the ambition of the complexity of achieved change (Janebová \& Bartáková, 2001).

Social pedagogy, unlike social work, devotes significantly greater effort to preventative work with so called "healthy and non-problematic" individuals, contributing to the development of a healthy lifestyle and to the quality of life. It also helps individuals in terms of secondary prevention. It is therefore clear that the goals of both disciplines partly overlap mainly in secondary and tertiary prevention. Social work as well as social pedagogy focuses on helping risk individuals. From the above mentioned, is clear that the optics of social work is mainly "practical" oriented, focused on the goal. Formal object of social work is a "change of unfavourable social situation." View of the material 
object of social work, a relationship of an individual and a society, is a view through a deviation from the norm, through deviance. The view of social pedagogy is little different. It has no need to view relationship of a man and a society via the filter of social deviance. It is interested in this relationship in the long term, with the aim of optimal personality development and formation of a healthy lifestyle.

Social pedagogy and social work have, undoubtedly, similar functions. The convergence theory of social work and social pedagogy represents so called "demilitarized zone" between militant supporters of Social Work and opponents of social pedagogy on the one side, and conservative social pedagogues, who are highlighting differences between social work and social pedagogy, on the other side (Ondrejkovič, 2000).

Sachße (1987) cites three reasons for pedagogization of social work:

- The clientele of of social work has changed: It does not include only minority groups of society, but it aims at a wider population.

- The differences between educational institutions and institutions of social work are increasingly diminishing.

- Methods, principles and measures of social work are increasingly resembling educational methods.

Pedagogization of social work is desirable, especially, in the area of social prevention, namely in drop-in centers for children and youth, social activation services for families with children, and social rehabilitation services. These facilities are, by the law, included in the group of social prevention services and their primary target group are mainly children and youngsters. An Act No. 108/2006 Coll. (2006) defines activities that form a group of mandatory offered activities, these being:

- Educational and motivational activities.

- $\quad$ Activities mediating contacts with a social environment.

- $\quad$ Social therapeutic activities.

- $\quad$ Assistance with asserting rights, justified interests and dealing with personal matters.

As is evident from the Act itself the main target group of these services are children and youth. Activities mentioned are educational, training, and motivational activities. The field of training and educational activities is in competence of social pedagogue, whose professional contribution may be a welcomed enrichment to the area.

"Regarding the actual work with clients, in the spirit of this law, I believe that the current concept of social work is designed for working with clients, who have at least a minimal ability to define their social needs. If the client is recognized as being inneed he or she is offered a range of services, from which they themselves select the services they want to use. In cases where the client is a child the situation is complicated by the fact that the very process of negotiating the form of help is for the child very demanding and sometimes may even be in disagreement with the child's understanding of the world. The model of service provision to children should be based on the concept of social pedagogy, because it better reflects the needs of children clients than the concept of social work, which is more suitable for the work with adult clients" (Caltová Hepnarová, 2009, p. 82).

A similar situation occurs in the case of facilities for children requiring immediate assistance. These facilities are governed by The Act No. 359/1999 Coll. (1999), and fall under the Ministry of Labour and Social Affairs. Their main objective is to provide protection and assistance to vulnerable children for the necessary period of time (usually a few weeks or months). They fulfill, to the certain extent, the objectives of school facilities, for example children's homes. By the law, facilities for children requiring immediate assistance have to provide, among other things, educational care. Legislation governing school facilities (e.g. children's homes) establishes the level of professional competence of 
the pedagogical staff, the same is not true in the case of facilities for children requiring immediate assistance. The same situation is at schools. Social work is there also discussed. For example, Hopf states that social work at school should act preventively and help students and teachers with overcoming critical situations, and it should also define the objectives and tasks of social work at school. According to Hopf (2001), social work at school should:

- Prevent deviation in the behaviour of pupils in schools.

- $\quad$ Promote social competence of children and youth by targeted events and offers.

- Mediate the youth free time activities outside the school and their activities within the school environment.

- $\quad$ Look after groups of pupils with the consent of pupils and teachers.

- $\quad$ Alert the parents of socially handicapped pupils if they have the need of assistance or support means.

Even though Hopf (2001) speaks about social work (in German concept), it is clear that he means in fact social pedagogy.

\section{Social work and social pedagogy in practice}

Even with a different concept in theory, approaches of social pedagogy and social work mingle in practice. Social Work provides assistance primarily in the material area, while social pedagogy in social and educational area. The work of Lukas (1979), but also some other works (Bakošová, 2006; Kraus, 2001, 1996; Ondrejkovič, 2000) show mingling themes and areas of practice of both disciplines. A brief comment regarding those themes follows.

Lukas states that in the approach, which stresses social work aspects and suppresses aspects of social pedagogy, interest in work with older people used to be found. Today, however, even this is not true. In foreign countries, and also, recently, in our retirement homes, animators and moderators of free time are trying to fulfil seniors' free time with meaningful activities. This effort clearly is a pedagogical activity. The two approaches, in the concept of this work, can be found in two areas. An area determining social benefits can be viewed as explicitly social work oriented, and an influence of free time of children and youth can be seen as a purely pedagogical activity (for example in children houses). There are areas where the social pedagogical aspects of social activities directly interferes with social work. It is prominent in a work with youth and children. Work of social assistant and curator is a matter of social work as well as of social pedagogy.

Some specifics of both approaches can be illustrated by a concrete example (Janebová \& Bartáková, 2001). Let's imagine a young unemployed Gipsy with primary education, addicted to heroin. What can be offered by every area of practical activities? The aim is to create a social change towards full integration into society. While social work is primarily focused on basic needs and physiological needs, social pedagogy is focused more on the highest needs (meta-needs), for example personal fulfilment. An area where both disciplines meet is the area of higher psychological needs.

Some difference is manifested in the ambitions of both professions. While social work approaches the client pragmatically in order to, at least, diminish the risks associated with their behaviour, social pedagogy aims to change the personality of the client. In this sense, social work operates with a wider variety of deviant behaviour and therefore aims at wider range of goals. An objective of social work can be "a very small change" as is for example a usage of a sterile needle or a change of the way of drug intake from injection to inhalation. Social pedagogy demands more from the clients, it aims to influence them so as to be able to live in a given society. 
An important factor of social pedagogy is also working with the clients even after they have overcome their problems (heroin abuse, unemployment, and social exclusion) in a sense of supporting the development of free, fulfilled, happy life style within the standards of society.

At this point it is possible to identify another significant difference between the two approaches. In social work a strong emphasis is on termination, an end of work with the client. Among other things, this is due to contracts. There is an increasing tendency to sign a contracts with the client, defining goals of the work with the client, means to achieve those objectives, and their evaluation criteria, on what principles will the achievement of those goals be controlled. A fulfilment of those objectives relatively clearly determines the end of work with the client.

An accurate term to describe a process happening within social pedagogy is social education. But this is a term that appears also in social work, even in official documents. Let us take The Educational Standards of Social Work within which it is commonly spoken about. The problem being that it is not defined. It's just a typical activity of the Czech social worker. It is probably one of following activities: "providing social help (including a range of professional activities from counselling through therapy and training to management, negotiation, and representation), aiming at improving of client's psychosocial functioning; better use of different client's sources from intra-psychic and interpersonal to social sources; causing a social change that is beneficial to the client in the social environment" (Tomeš et al., 1997, p. 29).

Pedagogical Dictionary defines social education as a development of social skills of an individual. Its aim is to equip students with knowledge, skills, habits and attitudes that are necessary for their life in a society with other people (Průcha, Walterová, \& Mareš, 2013). The objective of social education in social work is to ensure that the client no longer needs an assistance of a social worker, he or she is able to manage their own problems. Moreover the clients will no longer get themselves into any problems in general. Social education in the context of social pedagogy assumes a focus of an individual on relationships, on moral profile and social activity. A term "personality and social development" is also used (Kraus, 2014, p. 66).

\section{Conclusion}

The analysis of paradigms of both fields confirmed our starting hypothesis that the basic paradigm is essentially homogeneous. It is desirable to build up the identity of our scientific disciplines and professions, and also to mutually benefit from learned findings. In The Czech Republic, however, social work, as was already mentioned, ignores social pedagogy. It is obvious that the process of finding the boundaries between social work and social pedagogy is happening more in theoretical level than in practical level. The situation in practice is different from the theory. Members of both professions are often meeting the same clients in similar situations and are often using similar methods to meet the same goals. Sometimes they even compete for the same jobs. In this sense, they are sometimes rather competitors.

The fact that in our country, social pedagogue as a profession has no legislative basis, is partially compensated by the fact that it is entirely legitimate for graduates in Social Pedagogy to find an employment within the department of Ministry of Education, Youth and Sports (under the Act on Pedagogical Staff of 2004), and in the field of social work (under the Act on Social Services of 2006).

\section{References}

Act No. 108/2006 Coll., on social services. (2006). Retrieved from https://portal.gov.cz/app/zakony/zakon.jsp?page=0\&nr=108 2F2006\&rpp=15\#seznam 
Act No. 359/1999 Coll., on the social and legal protection of children. (1999). Retrieved from https://portal.gov.cz/app/zakony/zakonPar.jsp?idBiblio=48272\&nr=359 2F1999\&rpp=15\#local -content

Bakošová, Z. (2006). Sociálna pedagogika jako životná pomoc. Bratislava: FFUK.

Bon, C. (2009). Social pedagogy in France. In J. Kornbeck, \& R. Rosendal Jensen (Eds.), The diversity of social pedagogy in Europe: Vol. VII: Studies in comparative social pedagogies and international social work and social policy (pp. 34-45). Bremen: Europäisher Hochschulverlag. doi:10.1080/13691457.2012.750501

Brągiel, J. (2001). Miejsce pracy socjalnej w polskiej pedagogike spolecznej. In Socialia 2001, Sociální práce a ostatní společenskovědní discipliny (pp. 9-12). Hradec Králové: Gaudeamus.

Braches-Chyrek, R., \& Süncker, H. (2009). Will social pedagogy disappear in Germany? In J. Kornbeck, \& R. Rosendal Jensen (Eds.), The diversity of social pedagogy in Europe: Vol. VII: Studies in comparative social pedagogies and international social work and social policy (pp. 169-189). Bremen: Europäisher Hochschulverlag. doi:10.1080/13691457.2012.750501

Caltová Hepnarová, G. (2009). Uplatnění sociálního pedagoga v sociálních službách. In Sociální pedagogika ve střední Evropě, současný stav a perspektivy (pp. 81-88). Brno: IMS.

Cameron, C., \& Moos, P. (Eds.). (2011). Social pedagogy and working with children and young people: Where care and education meet. London and Philadelphia: Jessica Kingsley Publishers. doi:10.1080/0312407X.2013.809676

DuBois, B., \& Miley, K. K. (1992). Social work: An empowering profession. Boston: Allyn and Bacon.

Eriksson, L., \& Markström, A.-M. (2004). Interpreting the concept of social pedagogy. In A. Gustavsson, H.-E. Hermansson, \& J. Hämäläinen (Eds.), Perspectives and theory in social pedagogy (pp. 9-23). Göteborg: Daidalos. doi:10.1080/13691450601143864

Eriksson, L., \& Markström, A.-M. (2009). Social pedagogy in a Swedishcontext. In J. Kornbeck, \& R. Rosendal Jensen (Eds.), The diversity of social pedagogy in Europe: Vol. VII: Studies in comparative social pedagogies and international social work and social policy (pp. 46-64). Bremen: Europäisher Hochschulverlag. doi:10.1080/13691457.2012.750501

Erler, M. (1993). Soziale Arbeit. München: Juventa Verlag.

Hämäläinen, J. (1989). Social pedagogy as a meta-theory of social work education. International Journal of Social Work, 32(2), 117-128. doi:10.1177/002087288903200206

Hämäläinen, J. (2003). Developing social pedagogy as an academic discipline. In A. Gustavsson, H.-E. Hermansson, \& J. Hämäläinen (Eds.), Perspectives and theory in social pedagogy (pp. 133-153). Göteborg: Daidalos. doi:10.1080/13691450601143864

Hochstrasser, F. (1991). Sociálna pedagogika vo Švajčiarsku. Vychováteĺ, 2, 21-22.

Hopf, A. (2001). Sociální pedagogika ve škole. Praha: PdF UK.

Hroncová, J., Hudecová, A., \& Matulayová, T. (2001). Sociálna pedagogika a sociálna práca. Bánská Bystrica: PF UMB.

Huppertz, N., \& Schinzler, E. (1995). Grundfragen der Pädagogik. Koln-Munchen: Stam Verlag.

International Journal of Social Pedagogy (2016, February 4). Them pra social pedagogy, centre for understanding social pedagogy, UCL Institute of Education. Retrieved from http://www.internationaljournalofsocialpedagogy.com

Janebová, R., \& Bartáková, A. (2001). Sociální práce a sociální pedagogika v kontextu teorie a praxe: symbionti nebo konkurenti? In Socialia 2001. Sociální práce a ostatní společenskovědní disciplíny (pp. 60-68). Hradec Králové: Gaudeamus. 
Kantowicz, E. (2013). Pedagogika (w) pracy socjalnej. Olsztyn: Wydawnictwo Uniwersytetu Warminsko-Mazurskiego.

Kappl, M. (2008). Vývojové modely sociální práce a jejich metafory. In Sborník z konference $V$. Hradecké dny sociální práce: Posuzování životní situace v sociální práci (pp. 44-58). Hradec Králové: Gaudeamus.

Knotová, D. (2004). Jaká je současná sociální pedagogika? In Konstituování sociální pedagogiky jako vědního oboru (pp. 368-376). Brno: IMS.

Kratochvílová, E. (2001). Pedagogika vol'ného času, sociálna pedagogika a sociálna práca. Pedagogická revue, 53(5), 415-423.

Kraus, B. (1996). Pohled na současnou sociální pedagogiku. Pedagogika, 46(2), 117-124.

Kraus, B. (2001). Vztah sociální práce a sociální pedagogiky. In Sociália 2001. Sociální práce a ostatní společenskovědní disciplíny (pp. 60-68). Hradec Králové: Gaudeamus.

Kraus, B. (2014). Základy sociální pedagogiky. Praha: Portál.

Kraus, B., \& Poláčková, V. (Eds.). (2001). Člověk - prostředí - výchova: K otázkám sociální pedagogiky. Brno: Paido.

Kuhn, T. S. (1997). Struktura vědeckých revolucí. Praha: Oikúmené.

Leliūgienè, I. (2003). Socialinè pedagogika: vadovèlis. Kaunas: Technologija.

Leliūgienè, I., Giedraitienè, E., \& Rupšienè, L. (2006). Socialinių darbuotojų/socialinių pedagogu rengimas Lietuvoje [Training Social Workers/Social Pedagogues in Lithuania]. Pedagogika, 4(83), 64-73.

Levická, J. (2002). Teoretické aspekty sociálnej práce. Trnava: FZaSP TU.

Lipskij, I. A. (2004). Socialnaja pedagogika. Moskva: Sfera.

Lukas, H. (1979). Sozialpädagogik - Sozialarbeitwissenschaft. Berlin: Verlag Solker Spiess.

Madsen, B. (2006). Sosialpedagogikk. Oslo: Universitetsforlaget.

Marynowicz-Hetka, E. (2008) Pedagogika spoleczna i prácasocjalna - analizazwiazkóv z punktu widzeniaspoleczno-pedagogicznego. In Sociálna pedagogika, sociálna práca a sociálna andragogika - aktuálne otázky teorie a praxe (pp. 15-22). Prešov: FF.

Mollenhauer, K. (1966). Zur Bestimmung von Sozialpädagogik und Sozialarbeit in der Gegenwart. Wienheim: Beltz Verlag.

Navrátil, P. (1998). Sociální práce jako sociální konstrukce. Sociologický časopis, 34(1), 37-50.

Nikitin, B. A. (Ed.). (2002). Socialnaja pedagogika. Moskva: Vlados.

Noack, W. (2001). Sozialpädagogik. Einlehrbuch. Freiburgim Breisgau: Lambertus.

Ondrejkovič, P. (2000). Príspevok k otázkam vztahov sociálnej pedagogiky a sociálnej práce. Pedagogika, L(2), 181-192.

Ondrejkovič, P. (2004). Poznámky ku konštituovaniu sociálnej pedagogiky jako vedy. In Konstituování sociální pedagogiky jako vědeckého oboru (pp. 78-87). Brno: IMS.

Payne, M. (1997). Modern social work theory. Houndmills, Basingstoke, Hampshire and London: Mamillan Press LTD.

Petrie, P. (2001). The potential of pedagogy/education for work in the children's sector in the UK. Social Work in Europe, 8(3), 23-26. 
Petrie, P., \& Cameron, C. (2009). Importing social pedagogy? In J. Kornbeck, \& R. Rosendal Jensen (Eds.), The diversity of social pedagogy in Europe: Vol. VII: Studies in comparative social pedagogies and international social work and social policy (pp. 145-168). Bremen: Europäisher Hochschulverlag. doi:10.1080/13691457.2012.750501

Pfeiffer, R. (1994). Sozialarbeit und sozialpädagogik in handlungsteoretischer perspektive. Pädagogik und Schulalltag, (2), 225-230.

Pilch, T., \& Lepalczyk, I. (1995). Pedagogika spoleczna. Warszawa: Źak.

Průcha, J., Walterová, E., \& Mareš, J. (2013). Pedagogický slovník. Praha: Portál.

Radziewicz-Winnicki, A. (2008). Pedagogika spoleczna w obliczu realiów codziennośti. Warszawa: Wydawnictwa Akademickie i Profesjonalne.

Sachße, CH. (1987). Die pädagogisierung der gesellschaft und die professionalisierung der sozialarbeit. In S. Müller, Handlungskompetenz in der Sozialarbeit/Sozialpädagogik II. Bielefeld: AJZ Druck Verlag.

Schilling, J. (1999). Sociálna práca. Hlavné smery vývoja sociánej pedagogiky a sociálnej práce. Trnava: TU.

Strieženec, Š. (2000). Vzt́ah sociálnej práce a sociálnej pedagogiky. In Z. Bakošová (Ed.), Súčasný stav sociálnej pedagogiky na Slovensku. Zborník referátov z vedeckej konferencie s medzinárodnou účastou konanej v dňoch 2. 2. - 3. 2. 2000 v Bratislave. Bratislava: FFUK.

Szmagalski, S. J. (2010). Czy pedagogika społeczna przyjmie się w Wielkiej Brytanii? Tradycje i nowe tendencje w brytyjskiej pracy socjalnej. In M. Ciczkowska-Giedziun, E. T. Kantowicz, \& B. Chrostowska (Eds.), Szkoły polskiej pedagogiki społecznej wobec nowych wyzwań .Polska pedagogika społeczna na poczqtku XXI wieku. Warszawa: Uniwersytet Warszawski, Wydział Stosowanych Nauk Społecznych i Resocjalizacji.

Tokárová, A. (2008). Sociálna práca ako vedná disciplína. In Sociálna pedagogika, sociálna práca a sociálna andragogika - aktuálne otázky teorie a praxe (pp. 15-22). Prešov: FF.

Tokárová, A. (Ed.). (2003). Sociálna práca. Prešov: Akcent print.

Tomeš, I. (Ed.). (1997). Vzdělávací standardy v sociální práci. Praha: Sociopress/Socioklub.

Vaitkevicius, J. (1995). Socialinės pedagogikos pagrindai: vadovélis aukštosioms mokykloms. Vilnius: Egalda.

Wagner, A. (1998). Debata o pracy socjalnej/pedagogice spolecznej - reprezentujeme homogeniczny czy heterogeniczny paradygmat naukowy. In E. Marynowicz-Hetka (Ed.), Pedagogika szpoleczna jako disciplína akademicka (pp. 455-462). Lódž: Wydawnictwo Uniwersytetu. 